\title{
Symphysis pubis distance in adults: a retrospective computed tomography study
}

\author{
Banu Alicioglu • Ozcan Kartal · Hulya Gurbuz • \\ Necdet Sut
}

Published online: 26 February 2008

(C) Springer-Verlag 2008

Erratum to: Surg Radiol Anat (2008) 30:153-157

DOI 10.1007/s00276-007-0295-0

The correlation coefficient between the posterior SP distances and age are expressed as follows:

The results section of the abstract in the first page third line:

$(r=-0.150 ; P<0.001)$

In Table 2

$r=-0.150, P<0.001$

The online version of the original article can be found under doi:10.1007/s00276-007-0295-0.

B. Alicioglu $(\bowtie) \cdot$ O. Kartal

School of Medicine, Department of Radiology,

Trakya University, 22030 Edirne, Turkey

e-mail: banualicioglu@trakya.edu.tr; banu_alici@yahoo.com

H. Gurbuz

Department of Anatomy, Faculty of Medicine,

Istanbul Bilim University, Istanbul, Turkey

N. Sut

Faculty of Medicine, Department of Biostatistics,

Trakya University, Edirne, Turkey 